\title{
Mechanical behaviour at high temperature of alkali-activated aluminosilicates (geopolymers)
}

\author{
Antonia Martin, Jose Y. Pastor, Angel Palomo, Ana Fernández Jiménez
}

G R A P H I C A L A B S T R A C T
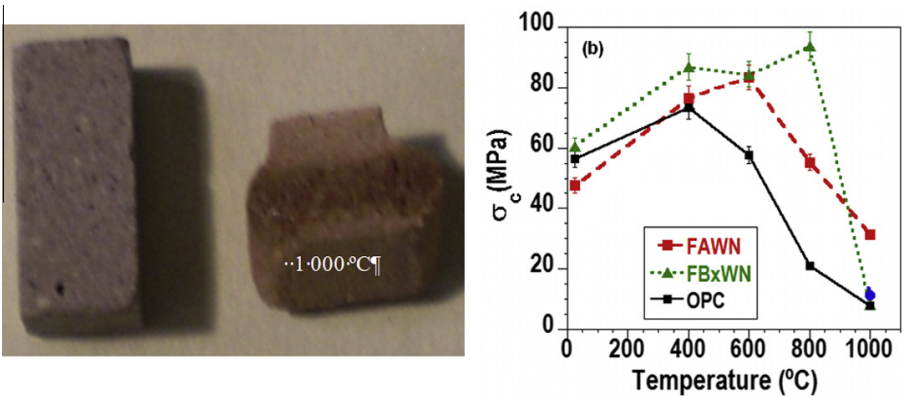

A B S T R A C T

This study was designed to determine the effect of temperature on the mechanical strength (in both in vivo and post-exposure trials) of two alkaline cements (without OPC): (a) 100\% fly ash (FA) and (b) $85 \% \mathrm{FA}+15 \%$ bauxite, the activated alkaline solution used was $85 \% 10-\mathrm{M} \mathrm{NaOH}+15 \%$ sodium silicate. A Type I $42.5 \mathrm{R}$ Portland cement was used as a control. Two series of trials were conducted: (i) in vivo trials in which bending and compressive strength, fracture toughness and modulus of elasticity were determined at different temperatures; and (ii) post-firing trials, assessing residual bending and compressive strength after a 1-h exposure to high temperatures and subsequent cooling. The findings showed that from 25 to $600{ }^{\circ} \mathrm{C}$, irrespective of the type of test (in vivo or post-firing), compressive mechanical strength rose, with the specimens exhibiting elastic behaviour and consequently brittle failure. At temperatures of over $600{ }^{\circ} \mathrm{C}$, behaviour differed depending on the type of test: (i) in the in vivo trials the high temperature induced pseudo-plastic strain and a decline in mechanical strength that did not necessarily entail specimen failure; (ii) in the post-firing trials, compressive strength rose.

\section{Introduction}

While thermal conductivity in Portland cement-based concrete is low and the material is non-combustible, sustained exposure to fire causes severe spalling and as a result structural damage or even collapse, with the obvious consequences of risk to human life and high economic costs [1-3].
Portland cement paste plays a predominant role in that behaviour. At $95^{\circ} \mathrm{C}, \mathrm{C}-\mathrm{S}-\mathrm{H}$ gel dehydrates and shrinks substantially, while tiny explosions take place in the material. At $450{ }^{\circ} \mathrm{C}$ portlandite and at $750^{\circ} \mathrm{C}$ calcium carbonate decompose. When the cement rehydrates on contact with water, it disintegrates [3].

In recent years, a new family of aluminosilicate binders called alkaline cements or geopolymers has been the subject of considerable attention [4-9]. When are hydrated in the presence of alkalis, these materials (such as metakaolin or fly ash) yield a three-dimensional alkaline aluminosilicate hydrate known as 
$\mathrm{N}-\mathrm{A}-\mathrm{S}-\mathrm{H}$ gel, which differs from the $\mathrm{C}-\mathrm{S}-\mathrm{H}$ gel generated in Portland cement hydration $[10,11]$. The secondary reaction products include several types of zeolites, including hydroxysodalite, Na-chabazite and zeolite P. The amount and type of such zeolites depends on the nature of the alkaline activator used and the curing conditions [6-13]. The properties that best define these alkaline cements are indisputably their ability to develop high mechanical strength in a short period of time at moderate temperatures $\left(T<100^{\circ} \mathrm{C}\right)[6,14]$ and their excellent durability [15-23].

The findings published to date on their fire resistance and performances under high temperature conditions are promising. All reports concur that these materials perform better than Portland cement, for at $600-800{ }^{\circ} \mathrm{C}$ and greater, in most cases their compressive strength rises after cooling [19-24].

Davidovits [24] deemed that certain of the binders he synthesised (( $\mathrm{Na}, \mathrm{Ca})$-polysialate and (K,Ca)-polysialate-silox) exhibited excellent fire resistance up to $1200^{\circ} \mathrm{C}$. Barbosa and Mackenzie [19] obtained similar results for sodium silicate + caustic soda-activated metakaolin, observing that while the material shrank slightly due to water loss from 100 to $200{ }^{\circ} \mathrm{C}(\approx 15 \%$ hydration water), at $250-800^{\circ} \mathrm{C}$ it could be regarded as essentially dimensionally stable. At $800{ }^{\circ} \mathrm{C}$ it shrank due to rising density or volume change induced by the crystallisation of new phases. These authors, however, do not believe that this shrinkage could be due to a melting point or viscous creep. In any case, they consider that this process ceases abruptly at $880-900{ }^{\circ} \mathrm{C}$. Then the sample maintains its dimensional stability until it finally fused at temperatures of $1000-1300{ }^{\circ} \mathrm{C}$, depending on slight variations in composition. Bakharev [20] found that fly ash activated with Na-containing activators exhibited shrinkage cracking and a rapid decline in strength at $800{ }^{\circ} \mathrm{C}$, events related to a drastic increase in the average pore size. The loss of strength on firing may have been associated with the deterioration of the aluminosilicate gel.

According to most of the papers published to date [19-29], these materials reach a critical point at around $600-800{ }^{\circ} \mathrm{C}$. In that temperature range, paste dimensional stability is seriously affected, which impacts bending strength substantially. In contrast, compressive strength measured on post-firing cold samples rises; an effect attributed to the partial sintering that takes place at such temperatures.

Some of the papers reviewed centre on how to control these dimensional changes and raise material resistance to high temperatures. Krivenko and Kovalchuk [21], for instance, observed that the formation of a given percentage of thermostable zeolites in the starting cements raises dimensional stability at high temperatures considerably. Most authors [21-29] found the starting cement composition ( $\mathrm{Si} / \mathrm{Al}$ ratio and alkali content) to be a determinant, with the liquid/solid ratio also affecting the results [34].

Alkalis, in turn, play a dual role which calls for a certain compromise in cement design. On the one hand, a high alkali content ( 8 or $12 \mathrm{M}$ ) is needed to accelerate the activation reactions in alkaline cements and obtain materials with high initial strength. As alkalis act as fluxes at high temperatures, however, their content must be limited to generate thermally stable materials.

The $\mathrm{SiO}_{2} / \mathrm{Al}_{2} \mathrm{O}_{3}$ ratio is another prominent factor: ratios of $2-4$ are known to raise initial material strength and to favour the formation of thermostable zeolites such as herschelite, faujasite and hydroxysodalite which induce recrystallisation in the material at high temperatures without severely affecting its structure [21]. Higher ratios hinder the formation of such zeolites and favour sintering. Lower ratios prompt the formation of large amounts of zeolites ([zeolites]>10\%) at high temperatures, raising internal stress in the material due to intense re-crystallisation [21].

Nearly all the aforementioned papers centre on the study of materials cooled after exposure to high temperatures (brief exposure to fire). Very little research has been conducted on these materials under conditions that may be regarded as real, i.e., in vivo, exposed to high temperatures while bearing structural loads.

Although more experimentally complex and entailing the use of highly sophisticated equipment, such studies have been successfully conducted in prior research. Some alkaline cements with specific compositions have been found to exhibit pseudo-plastic behaviour at high temperatures [22].

In keeping with that line of research, the present paper discusses an exhaustive study of in vivo mechanical behaviour, particularly failure behaviour, in alkaline cements at high temperatures. To that end, pastes were tested in vivo (on a load frame positioned inside an electric kiln) for compressive and three-point bending strength, fracture toughness and modulus of elasticity. In addition, after hot testing and cooling, a number of physical-mechanical and characterisation trials were run on the materials to gain a better understanding of their behaviour.

\section{Experimental}

Two materials were used in the present study, a fly ash (FA) from a Spanish coal-fired power plant (Aboño) and bauxite. The bauxite was used to modify the $\mathrm{Si} / \mathrm{Al}$ ratio because some authors [19-21] indicated that one of the most significant factors that affecting to the phases composition and mechanical behaviour of the geopolymer materials at high temperature is the initial chemical composition as well as the temperature of firing. The chemical composition of these materials, determined with X-ray fluorescence, is given in Table 1.

Two binders were studied (see Table 2) to determine the effect of slight compositional changes, namely $F A$ (100\% fly ash) and $F B x(85 \%$ FA $+15 \%$ bauxite). The same alkaline activator was used in both, $W N$ (a solution containing $15 \%$ sodium silicate $+85 \% 10-\mathrm{M} \mathrm{NaOH}$ ). The control was a water-hydrated CEM I 42.5 R Portland cement.

Different types of specimens were prepared with the pastes depending on the trial to be conducted. Further to the literature, the alkaline cements or geopolymer were initially cured at $85{ }^{\circ} \mathrm{C}$ for $20 \mathrm{~h}$ and $98 \%$ relative humidity [22]. The CEM I 42.5 $\mathrm{R}$ cement used as a control was cured at $22{ }^{\circ} \mathrm{C}$ and $98 \%$ relative humidity and stored in a climatic chamber for 6 months. All the materials were stored in a climatic chamber through the 6 months testing age.

The methodology followed in the in vivo and post-firing trials is described below.

\subsection{In vivo trials}

To ensure sample uniformity, a single block $(100 \times 100 \times 60 \mathrm{~mm})$ of paste was moulded with each cement. Six months later they were mechanised into smaller prismatic specimens of varying dimensions depending on the trial to be conducted: (a) $10 \times 4 \times 60 \mathrm{~mm}$ for the bending strength trials; (b) $5 \times 4 \times 30 \mathrm{~mm}$ for the fracture toughness trials; and (c) $4 \times 4 \times 8 \mathrm{~mm}$ (for a ratio of 2:1) for compressive strength testing. Prior to testing, all the specimens were measured with callipers with a precision of $0.01 \mathrm{~mm}$. At least four specimens were tested for each type of trial and experimental temperature: $25,400,600,800$ and $1000{ }^{\circ} \mathrm{C}$ in the compressive tests; $25,200,400$ and $600{ }^{\circ} \mathrm{C}$ in bending strength; 25,200 and $400{ }^{\circ} \mathrm{C}$ in the fracture toughness trials.

An original and unprecedented procedure was devised to notch the samples for the fracture toughness tests, in which indentation radii of around $20 \mu \mathrm{m}$ were attained, i.e., more than one order of magnitude lower than normally achieved with diamond wire saws. The procedure consisted of pre-notching the $5 \times 4 \times 30$-mm specimens to a depth of $0.8 \mathrm{~mm}$ with a $1 \mathrm{~mm}$ diamond saw. That pre-indentation cut a square out of the specimen profile. Industrial shaving razors were then used to make indentations smaller than the critical microstructural size of the material. The $150 \mu \mathrm{m}$ thick razors were set into the machine depicted in Fig. 1(a), specifically designed for this purpose. The razors were impregnated with a gel containing diamond powder and push-pulled (reciprocating motion) against the material until it was worn down to a depth of around $200 \mu \mathrm{m}$. The total length of the indentation was consequently around $1 \mathrm{~mm}$. Its depth on the fracture surfaces (after specimen failure) was determined with a profile projector with a resolution of $0.001 \mathrm{~mm}$. This method generates indentations practically equivalent to real cracks with minimal damage to the material (which is not the case with diamond saw notching) and yields a fracture toughness measure closer to the actual value.

The fracture toughness trials were conducted with a three-point bending (TPB) device in which the supporting pins were spaced at $20 \mathrm{~mm}$. The sample was positioned with the indentation on the side opposite the loaded surface and aligned with the centreline of the loading pin to ensure that when the force was applied, the specimen would fail along a crack generated at the back of the indentation. 
Table 1

Chemical composition of solids, determined with X-ray fluorescence.

\begin{tabular}{|c|c|c|c|c|c|c|c|c|c|c|c|}
\hline \multirow[t]{2}{*}{ Material } & \multirow[b]{2}{*}{${ }^{1}$ LoI } & \multicolumn{10}{|c|}{$\%(w t)$} \\
\hline & & $\mathrm{SiO}_{2}$ & $\mathrm{Al}_{2} \mathrm{O}_{3}$ & $\mathrm{Fe}_{2} \mathrm{O}_{3}$ & $\mathrm{MgO}$ & $\mathrm{CaO}$ & $\mathrm{TiO}_{2}$ & $\mathrm{~K}_{2} \mathrm{O}$ & $\mathrm{SO}_{3}$ & $\mathrm{Na}_{2} \mathrm{O}$ & Others \\
\hline${ }^{3} \mathrm{FA}$ & $2.23^{1}$ & 51.78 & 27.80 & 6.18 & 1.52 & 4.59 & 1.35 & 2.51 & 0.71 & 0.59 & 0.74 \\
\hline Bauxite & $12.80^{1}$ & 3.40 & 53.12 & 22.77 & 0.20 & 3.72 & 3.90 & - & & - & 0.09 \\
\hline${ }^{2}$ CEM I 42.5 R (control) & 3.28 & 21.13 & 4.16 & 3.80 & 0.13 & 63.34 & - & 0.74 & 3.06 & 0.25 & 1.043 \\
\hline
\end{tabular}

1 Loss on ignition from 25 to $1000^{\circ} \mathrm{C}$.

2 Cem I 42.5 R supplied by Molins, Catalunya, Spain.

${ }^{3} \mathrm{FA}=$ fly ash, $\left[\mathrm{SiO}_{2}\right]_{\text {Reactive }}=34.93 \% ;\left[\mathrm{Al}_{2} \mathrm{O}_{3}\right]_{\text {Reactive }}=16.95 \%[30,31]$

Table 2

Binders.

\begin{tabular}{llllll}
\hline Name & Solid & $\begin{array}{l}\text { Hydrating } \\
\text { liquid }\end{array}$ & $\mathrm{L} / \mathrm{S}$ & $\begin{array}{l}\text { Curing } \\
\text { conditions }\end{array}$ & $\begin{array}{l}\mathrm{SiO}_{2} / \mathrm{Al}_{2} \mathrm{O}_{3} \\
\text { ratio }^{2}\end{array}$ \\
\hline FAWN & $100 \% \mathrm{FA}$ & $\mathrm{WN}^{1}$ & 0.35 & $\begin{array}{l}20 \mathrm{~h} 85{ }^{\circ} \mathrm{C}, \\
98 \% \mathrm{RH}\end{array}$ & 1.86 \\
FBxWN & $\begin{array}{l}85 \% \mathrm{FA}+15 \% \\
\text { Bauxite }\end{array}$ & $\mathrm{WN}^{1}$ & 0.35 & $\begin{array}{l}20 \mathrm{~h} 85{ }^{\circ} \mathrm{C}, \\
98 \% \mathrm{RH}\end{array}$ & 1.41 \\
CEM I 42.5 R & Agua & $0.30 \begin{array}{l}20 \mathrm{~h} 22{ }^{\circ} \mathrm{C}, \\
98 \% \mathrm{RH}\end{array}$ & 5.18 \\
\hline OPC & & & & $98 \%$
\end{tabular}

${ }^{1} \mathrm{WN}=15 \%$ sodium silicate $+85 \% 10-\mathrm{M} \mathrm{NaOH}\left(21.03 \% \mathrm{Na}_{2} \mathrm{O}, 4.05 \% \mathrm{SiO}_{2}, 74.92 \%\right.$ $\mathrm{H}_{2} \mathrm{O}$ ).

2 Ratio in binder by weight

${ }^{3} \mathrm{OPC}=$ Ordinary Portland cement.

In the three-point bending tests, the supporting pins were spaced at $40 \mathrm{~mm}$ (around ten times the sample depth) [32,33]. All the compressive and bending strength and fracture toughness tests were conducted on an INSTRON 6866 test frame with a $1 \mathrm{kN}$ load cell. The loading pin travel rate was $50 \mu \mathrm{m} / \mathrm{min}$ throughout. The frame was positioned inside a kiln (see Fig. 1(b)). For a fuller description of the test conditions, see references $[22,23]$.

The modulus of elasticity values were obtained from the slopes on the bending test stress-strain curves $(\sigma-\varepsilon)$ graphed for four trial temperatures: $25,200,400$ and $600{ }^{\circ} \mathrm{C}$.

\subsection{Post-firing trials}

All the specimens were prepared from a single mix of each cement (five moulds with six $1 \times 1 \times 6 \mathrm{~cm}$ specimens). Four specimens were then tested to failure for bending strength and the two resulting pieces (eight in all) for compressive strength. These values were used as a reference. Four specimens (per test temperature and type of material) were then fired in an electric kiln for $1 \mathrm{~h}$ at temperatures of $200,400,600,800$ and $1000{ }^{\circ} \mathrm{C}$ and then abruptly cooled to ambient temperature. After thermal treatment they were tested to determine relative residual bending $\left(\sigma_{\mathrm{FR}}\right)$ and relative compressive $\left(\sigma_{\mathrm{CR}}\right)$ strength. Relative residual bending strength, $\sigma_{\mathrm{FR}}$, is defined as $\sigma_{\mathrm{R}} / \sigma_{\mathrm{FO}}$ where $\sigma_{\mathrm{FO}}$ is the flexural strength at room temperature and the relative residual compressive strength $\sigma_{\mathrm{CR}}=\sigma_{\mathrm{C}} / \sigma_{\mathrm{CO}}$ where $\sigma_{\mathrm{CO}}$ is the compressive strength at ambient temperature. See reference [22] for further details.

The starting materials and samples tested were analysed on a Philips PW 1730 ( $\mathrm{CuK} \alpha$ radiation) diffractometer. Samples were examined in the $5^{\circ}$ to $60^{\circ} 2 \theta$ range at a scanning rate of $2 \% \mathrm{~min}$.
The variation in material porosity and pore size distribution with temperature $\left(25,400,600800\right.$ and $\left.1000{ }^{\circ} \mathrm{C}\right)$ was determined on a Micromeritics 9320 mercury intrusion porosimeter designed for a pore size range of $200-0.075 \mu \mathrm{m}$.

\section{Results and discussion}

\subsection{Behaviour of materials tested in vivo}

These trials were designed to gain a fuller understanding of the mechanical performance of materials tested at high temperatures while simultaneously bearing a small pre-load.

The in vivo compression test findings for $(4 \times 4 \times 8 \mathrm{~mm})$ paste specimens are shown in Fig. 2. Here the alkaline cements could be tested up to $1000{ }^{\circ} \mathrm{C}$. By way of example, Fig. 2(a) depicts the physical appearance of a FAWN cement specimen before and after testing at $1000{ }^{\circ} \mathrm{C}$. Note that it was flattened without failing, generating a "barrel" effect. The strength values recorded are plotted against temperature in Fig. 2(b). In the control cement, these values began to decline at $400{ }^{\circ} \mathrm{C}$ while in the alkaline cements they rose up to $600{ }^{\circ} \mathrm{C}$ in FAWN and to $800^{\circ} \mathrm{C}$ in FBxWN. At temperatures of over $1000^{\circ} \mathrm{C}$, the alkaline cements were softened too much to determine compressive strength.

The compression test stress-strain curves for the trial temperatures are shown in Fig. 3. Fig. 4, in turn, contains an example of a stress-strain curve for a theoretical material exhibiting plastic behaviour. According to this curve, in non-brittle failure material, the elastic zone is delimited by the yield stress, i.e., the critical stress beyond which the material does not fully regain its original shape after the load is removed. In other words, the material is permanently deformed. Beyond that stress, it undergoes plastic deformation, exhibiting ductile behaviour.

A comparison of the Fig. 3 findings to the theoretical curve in Fig. 4 shows that at ambient temperature, 400 and $600^{\circ} \mathrm{C}$, both alkaline cements (FAWN and FBxWN) exhibited the linear elastic behaviour characteristic of brittle materials. At higher temperatures, from 800 to $1000^{\circ} \mathrm{C}$, their behaviour of alkali cements was plastic, with permanent deformation. Portland cement, in contrast,
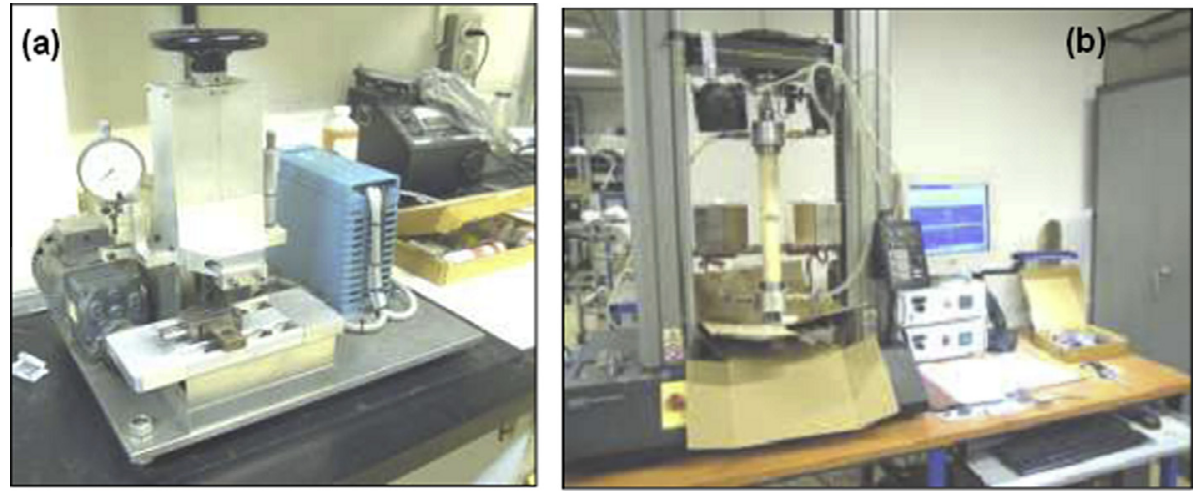

Fig. 1. (a) Notching apparatus; (b) loading frame. 

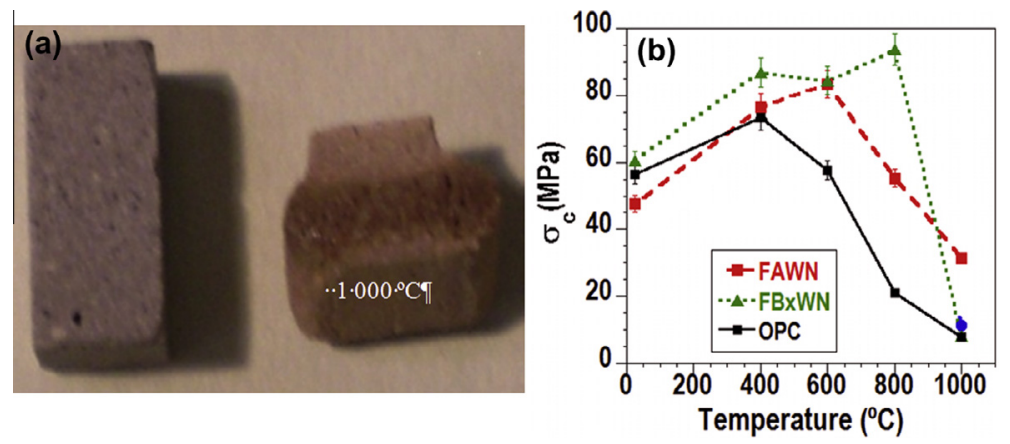

Fig. 2. In vivo compression tests: (a) FAWN cement before and after compression testing at $1000{ }^{\circ} \mathrm{C}$; (b) compressive strength versus temperature.
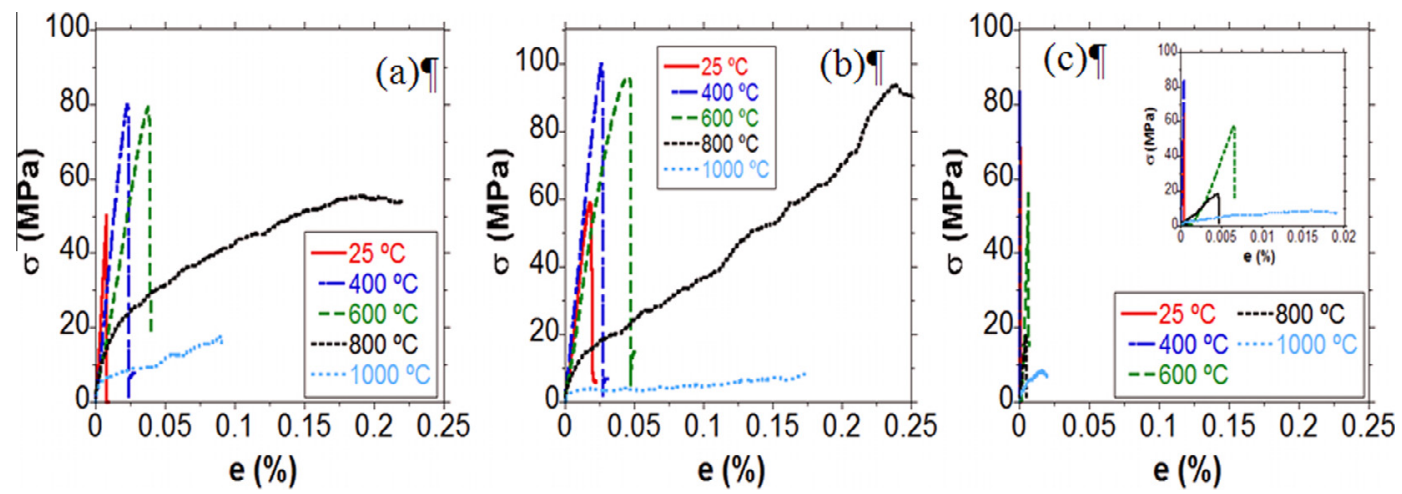

Fig. 3. In vivo compression test stress-strain curves at different temperatures for (a) FAWN, (b) FBXWN and (c) OPC.

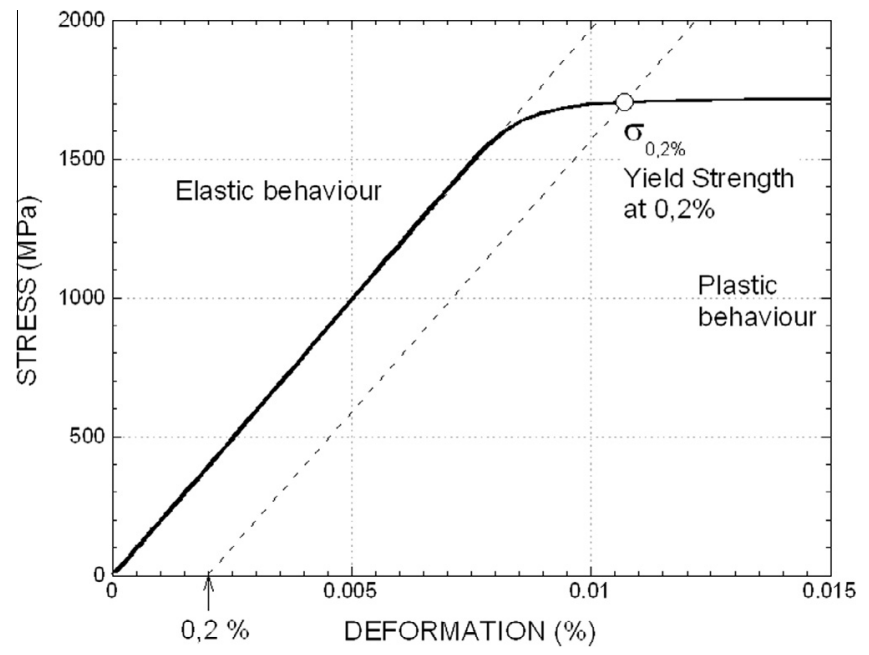

Fig. 4. Theoretical stress-strain curve for a material, based on compressive or bending strength testing.

exhibited brittle failure in the compression tests conducted at all the experimental temperatures. As expected, Portland cement performed well at ambient temperature. At $400{ }^{\circ} \mathrm{C}$, its mechanical strength continued to be competitive, with nearly negligible deformation. At higher temperatures its ultimate limit stress declined due to transformations taking place in its constituent phases [2,3].

Photographs of the $10 \times 4 \times 60 \mathrm{~mm}$ specimens before and after the in vivo three-point bending tests conducted at different temperatures are reproduced in Fig. 5. The colour change observed in FAWN and FBxWN was associated with the oxidation of the iron present in the starting materials, which muted from greyish green to brownish red in the materials tested at $600^{\circ} \mathrm{C}$ [34]. That explains why the colour change was more intense in FBxWN (Fig. 5 (c) sample at $600{ }^{\circ} \mathrm{C}$ ), which with $15 \%$ bauxite, had a higher iron content (see Table 1 ).

With rising temperature, the dehydration of the commercial OPC control became increasingly visible, its surface varying from a moist dark grey at ambient temperature to a dry light grey at $400{ }^{\circ} \mathrm{C}$.

The two alkaline cements, FAWN and FBxWN, behaved similarly at $25, \quad 200$ and $400^{\circ} \mathrm{C}$, with brittle failure (see Fig. 5(a) and (b)). At $600{ }^{\circ} \mathrm{C}$ they underwent permanent deformation, as confirmed below in the stress-strain curves, with a behavioural variation from linear elastic to plastic. After such significant deformation, their bending strength declined to nearly negligible due to microcracking across the entire surface, although they did not split into two halves. For that reason, in vivo bending tests could not be conducted on these materials at temperatures of over $600{ }^{\circ} \mathrm{C}$.

The OPC specimens could not be tested even at $600{ }^{\circ} \mathrm{C}$, for as Fig. 5(c) shows, at that temperature the material crumbled before it could be tested.

Fig. 6 shows the in vivo bending test findings. The alkaline cements performed better than the Portland cement control, as a rule. At ambient and all the test temperatures, the alkaline cement had higher ( $>10 \mathrm{MPa}$ ) bending strength than the Portland cement ( $\approx 6 \mathrm{MPa}$ ). Above $400^{\circ} \mathrm{C}$ the alkaline cements show a bending strength around $10 \mathrm{MPa}$ and a $600{ }^{\circ} \mathrm{C}$ around $7-8 \mathrm{MPa}$. At $600{ }^{\circ} \mathrm{C}$, mechanical strength was negligible in the control Portland cement, for, as noted earlier, the specimens collapsed before the value could be determined (see Fig. 5).

The bending test stress-strain curves are shown in Fig. 7. At 25, 200 and $400^{\circ} \mathrm{C}$, the alkaline cements (FAWN and FBxWN) exhibited linear elastic behaviour and brittle failure (as in the compression trials and as confirmed by the abrupt decline in the stress- 

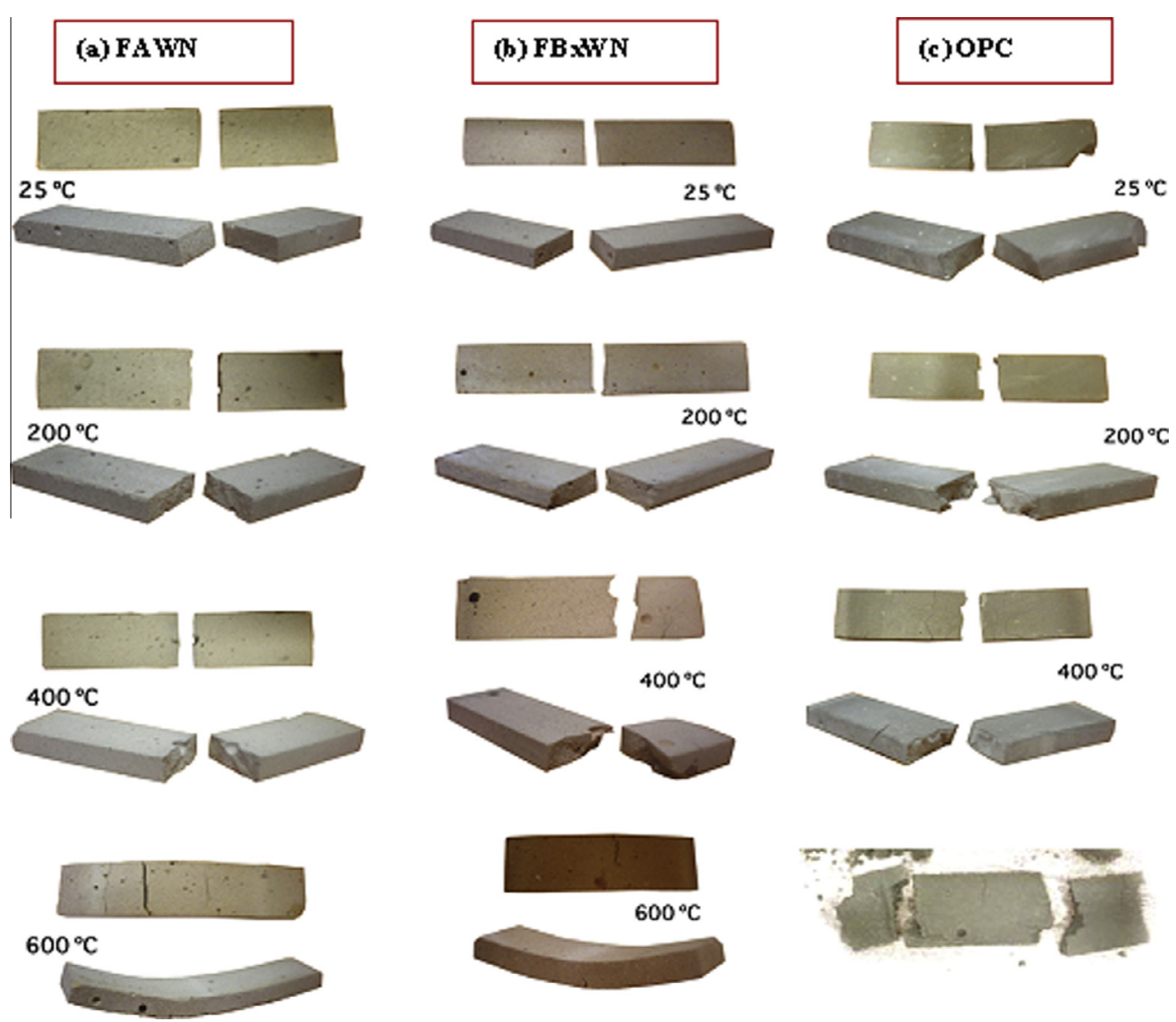

Fig. 5. Specimens before and after in vivo bending strength tests at different temperatures: (a) FAWN, (b) FBxWN and (c) OPC.

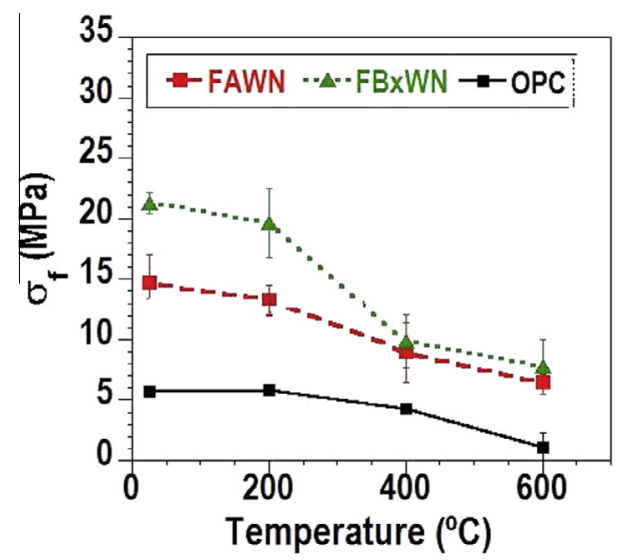

Fig. 6. In vivo three-point bending tests at different temperatures [the values for FAWN and FBxWN cements at $600^{\circ} \mathrm{C}$ are not significant because although it underwent deformation, the material did not fail: see Fig. 5(a) and b)].

strain curve) and yield strength declined with rising temperatures. At $600{ }^{\circ} \mathrm{C}$, despite the drastic decline in these materials' mechanical strength (to approximately one-sixth of the ambient temperature value), their stress-strain curves were indicative of plasticity. The Portland cement paste generated a bell curve typical of this material [35-38]. A first nearly linear stage in which cracks appeared but did not spread was followed by non-linear behaviour to the peak where abrupt failure occurred due to the growth and propagation of cracks and microcracks, and ultimately by a somewhat more gently sloped decline.

Fracture toughness is a measure of material resistance to brittle failure in the presence of a crack. This test was conducted on
$5 \times 4 \times 30 \mathrm{~mm}$ prismatic specimens, notched as described above (see Fig. 8(a)). The findings are given in Fig. 8(b) and the respective stress-strain curves in Fig. 9, which show the fracture toughness values for mode I plane strain $K_{\mathrm{IC}}$. The subscript I in $K_{\mathrm{IC}}$ means that this critical stress intensity factor, $K$, refers to mode I fracture at the crack tip [35-39]. Brittle materials, in which plastic strain at the tip of the crack is nil or negligible, have small $K_{\mathrm{IC}}$ values and are liable to catastrophic failure. $K_{\mathrm{IC}}$ values are fairly large for ductile materials, where processes zone are developed around the crack tip. In general, fracture mechanics is particularly useful for predicting catastrophic failure in materials with intermediate ductility values.

Fig. 8 shows that the $K_{\mathrm{IC}}$ values were low for all the cements tested, as expected in very brittle materials, although the values were slightly higher for the alkaline cements. Moreover, these values tended to decline with rising temperatures, again more abruptly in the Portland cement. At temperatures of $600{ }^{\circ} \mathrm{C}$ and higher, the alkaline cements (FAWN and FBxWN) exhibited a series of microcracks that prevented the material from bearing the pre-load. Once the test temperature stabilised and the load was raised, the material failed at a nearly nil load increase. The OPC could not be tested at $600{ }^{\circ} \mathrm{C}$ either, for at that temperature the material retained practically no strength.

The in vivo fracture toughness stress-strain curves (see Figs. 8 and 9) showed that the alkaline cements were tougher than Portland cement with rising temperature, inasmuch as the specific fracture energy (area under the $F-\delta$ curve) was larger in the later.

The relative modulus of elasticity at high temperatures was found from the slope in the elastic zone on the stress-strain curves obtained in the bending tests at different temperatures. Relative variations with temperature for each material are shown in Fig. 10, in which the modulus of elasticity for ambient temperature was assigned a value of 1 . As noted, the OPC underwent the 

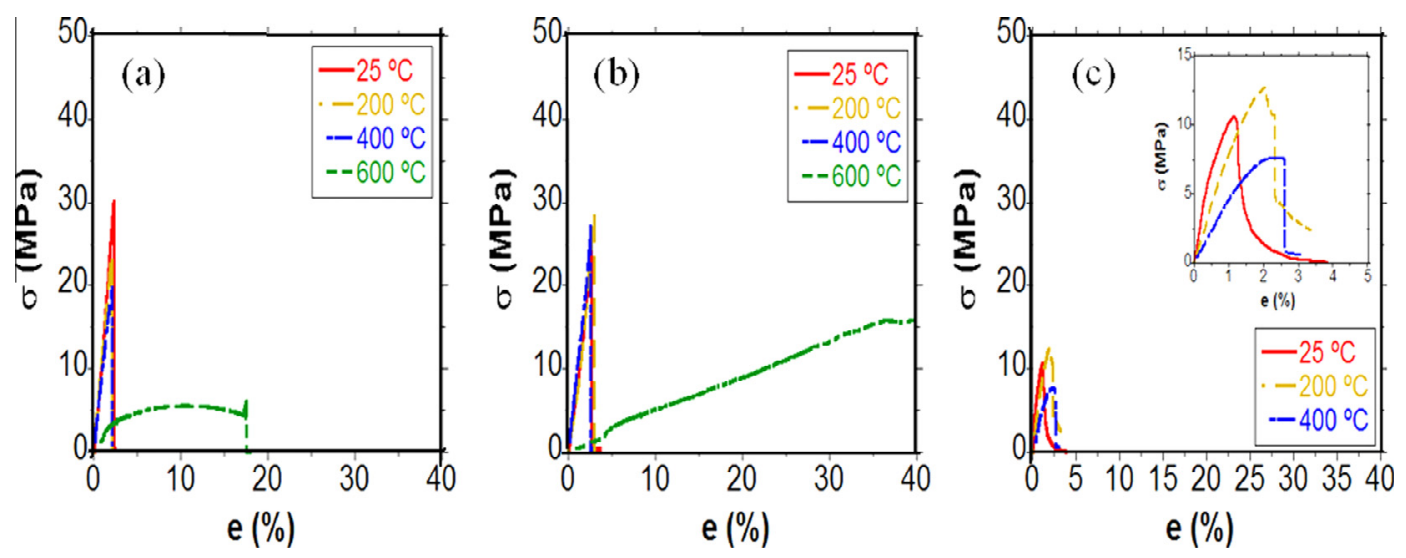

Fig. 7. In vivo bending test stress-strain curves for four test temperatures: (a) FAWN, (b) FBxWN and (c) OPC.

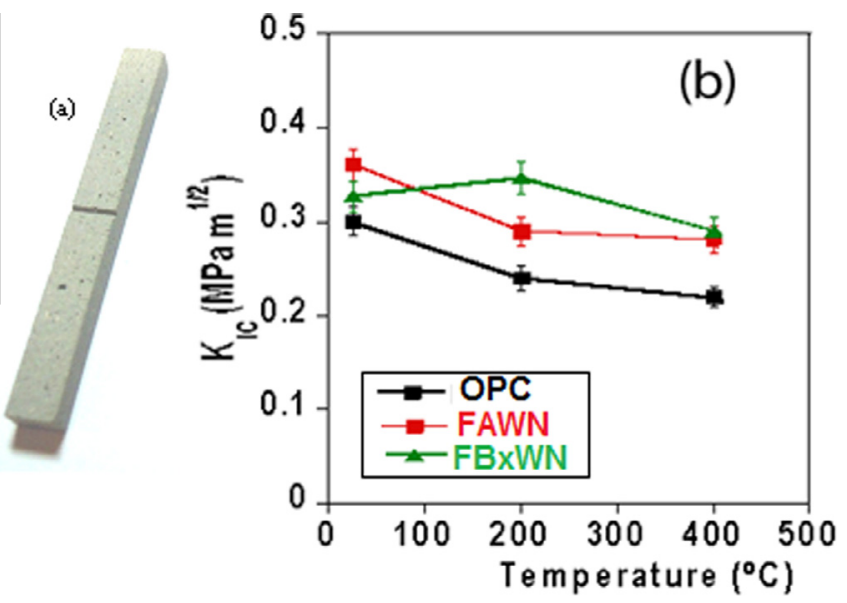

Fig. 8. (a) Pre-test specimen; (b) fracture toughness versus temperature.

greatest deterioration with temperature, with a modulus of elasticity that declined steadily to practically nil at $600^{\circ} \mathrm{C}$. The two alkaline cements behaved similarly to one another but differently from $\mathrm{OPC}$, with a very slow decline up to $400^{\circ} \mathrm{C}$ and more abruptly at $600{ }^{\circ} \mathrm{C}$.

\subsection{Post-firing trials}

As explained in the experimental section, mechanical behaviour was studied not only in the in vivo trials, but also in cold pastes subsequent to exposure to high temperatures (thermal shock).

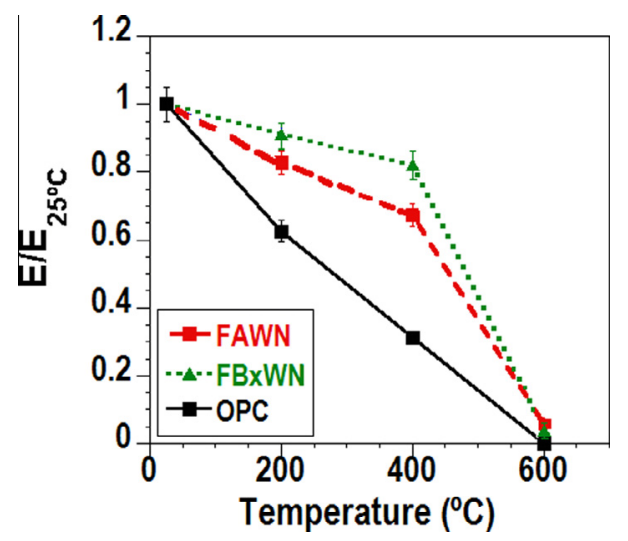

Fig. 10. Relative modulus of elasticity at high temperatures.
The temperature-induced variations in material mineralogy (XRD) and microstructure (porosity) were also determined.

Fig. 11 shows the residual bending (a) and compressive (b) strength values after the materials were exposed to different temperatures for $1 \mathrm{~h}$ and then cooled to ambient temperature during $20 \mathrm{~h}$. Between 25 and $600{ }^{\circ} \mathrm{C}$, bending strength declined slightly in the alkaline cements, rising slightly (especially compressive strength) at higher temperatures. In contrast, the residual strength values for Portland cement declined abruptly to practically nil at temperatures of $800^{\circ} \mathrm{C}$ or over. In both case bending and compressive strength sample FBxWN shows a better behaviour. The post-fired and cooled alkaline cements performed better in terms
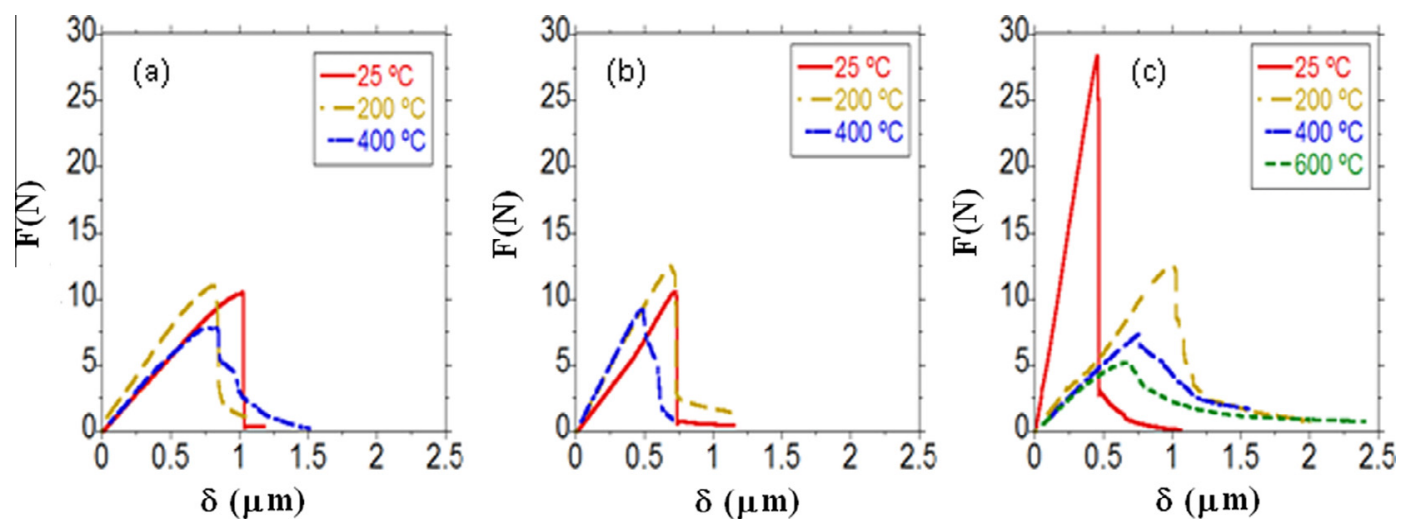

Fig. 9. Toughness stress-strain tests at different temperatures: (a) FAWN, (b) FBxWN, (c) OPC. 

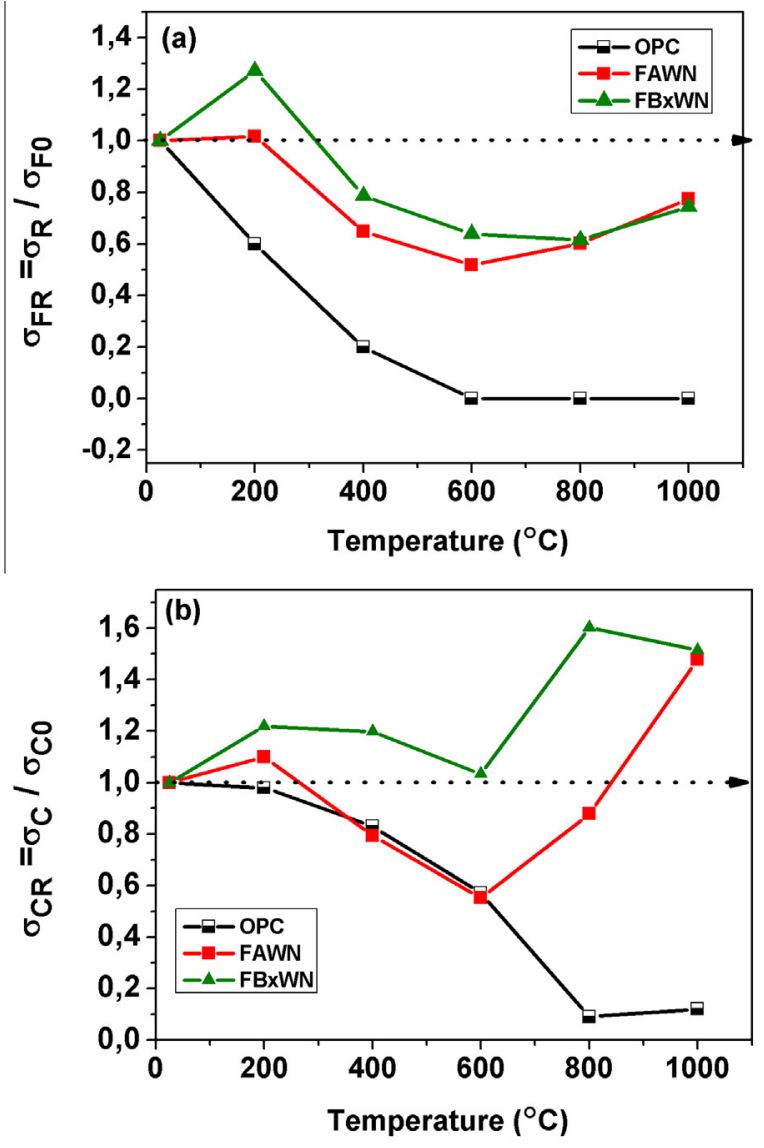

Fig. 11. Residual strength after 1 -h exposure to different temperatures: (a) bending strength $\left(\sigma_{\mathrm{FR}}=\sigma_{\mathrm{R}} / \sigma_{\mathrm{FO}}\right)$; (b) compressive strength $\left(\sigma_{\mathrm{CR}}=\sigma_{\mathrm{C}} / \sigma_{\mathrm{CO}}\right)$.

of compressive than bending strength due to the strain placed on the material. In both cases, bending and compressive strength, sample FBxWN shows a better behaviour, this could be in part associated with the lower $\mathrm{Si} / \mathrm{Al}$ compositions according to the previous works results [21] however other parameters are important as shown below.

Fig. 12 plots porosity and pore size distribution in the cooled alkaline cements versus firing temperature. Total porosity values appeared not to have been significantly affected by thermal treatment. Porosity grew very little between the initial temperature and $600{ }^{\circ} \mathrm{C}$ and turned slightly downward between 600 and $1000^{\circ} \mathrm{C}$. Nonetheless, exposure to high temperatures did seem to have a significant effect on pore size distribution (see Fig. 12(b) and (c)). The most prominent changes were observed at 600,800 and $1000^{\circ} \mathrm{C}$, when pore size increased significantly. That process may have been due to the fact that high temperatures transformed the liquid water present in the material to water vapour, which tended to escape, generating pressure on the pore walls and intensifying inter-pore connections to the detriment of smaller pores. The pore structure was able to absorb such stress, however, without inducing the spalling normally observed in OPC under similar conditions [2,3].

In another vein, the increase in pore size seemed to prompt a slight decline in effective porosity at $1000^{\circ} \mathrm{C}$. This redistribution of and slight decline in porosity at higher temperatures are consistent with the findings of other authors, who reported a rise in material density [27-28] as a result of exposure to high temperatures.

Fig. 13 reproduces the XRD patterns for the starting alkaline cements at ambient temperature and the material treated for $1 \mathrm{~h}$ at $800^{\circ} \mathrm{C}$, the temperature at which the most prominent mineralogical changes were observed, with the disappearance of some phases and crystallisation of others. The presence of a halo at ambient temperature for $2 \theta$ angles of $25-35^{\circ}$ was associated with the formation (as the majority product) of a N-A-S-H-type gel [610], the substance that affords the material its mechanical strength. The crystalline phases detected included quartz, mullite and hæmatite, present primarily in fly ash, and diaspore, a component of bauxite. These crystalline phases may be regarded as practically inert to alkaline activation [22,23,30]. Hydroxysodalite $\left(\mathrm{Na}_{4} \mathrm{Al}_{3} \mathrm{Si}_{3} \mathrm{O}_{12} \mathrm{OH}\right)$, a zeolite, appeared as a new crystalline phase and remained thermally stable up to $600{ }^{\circ} \mathrm{C}$ [21-22]. It disappeared at $800{ }^{\circ} \mathrm{C}$, giving way to nepheline $\left(\mathrm{NaAlSiO}_{4}\right.$ ) (see Fig. 12). The initial halo associated with the formation of $\mathrm{N}-\mathrm{A}-\mathrm{S}-\mathrm{H}$ gel was also observed to decline slightly in intensity and some of the crystalline phases present in the starting material that underwent no change during activation, such as the diaspore in FBxWN, tended to disappear.

The present findings showed that alkaline cements had higher mechanical strength and better fracture performance than the OPC control at high temperatures in both in vivo and post-firing trials.

For temperatures of under $600^{\circ} \mathrm{C}$, the two types of cements exhibited similar brittle failure behaviour, a condition in which plastic strain is generally absent and scant energy is absorbed during failure. The cracks formed when a load is applied are unstable and may spread rapidly; in other words, once formed, they continue to grow spontaneously with no load increase. The outcome is that at fairly low temperatures relative to the melting point, the material splits into two or more pieces in response to the static (i.e., constant or slowly increasing) stress applied.

At temperatures of $600{ }^{\circ} \mathrm{C}$ or over, however, the alkaline cements behaved differently from the control. Between 600 and $800{ }^{\circ} \mathrm{C}$, in the presence of a small load, the formation of a pseudo-viscous phase softened the former, which were deformed but did not (always) break (see Figs. 2 and 5). These materials exhibited pseudo-plastic behaviour, which would explain why their compressive strength rose after cooling (see Fig. 11) (an outcome not observed in OPC at any temperature), whereas their bending strength did not due to the dimensional changes taking place in the specimens. The control Portland cement lost consistency, crumbled or spalled (see Fig. 5).

Alkaline cements soften because certain components (usually the alkalis) melt sooner than others, forming with the non-molten constituents a plastic mass deformed by its own weight or an external load. At these temperatures they resemble but are not identical to ductile materials, which are known to normally undergo substantial plastic deformation with high energy absorption prior to failure. Ductile failure is characterised by a good deal of plastic strain in the area around the spreading crack. Moreover, the process takes place slowly as the crack spreads. Such cracks, whose propagation is constrained unless a heavier load is applied, are generally regarded as stable. Evidence of perceptible plastic strain (such as twisting and spalling) on the failure surface is also present.

The failure behaviour observed in alkaline cements at high temperatures may entail certain advantages over the brittle failure in OPC at the same temperature. Firstly, due to speedy and spontaneous crack propagation, brittle failure in OPC occurs suddenly and catastrophically, with no pre-warning. In alkaline cements the presence of plastic strain is a symptom of imminent failure, leaving room for preventive measures. Secondly, more strain is needed to induce ductile failure because ductile materials are by definition tougher.

Lastly, of the two types of alkaline cements tested here, cement FBxWN was observed to perform slightly better than FAWN in all 

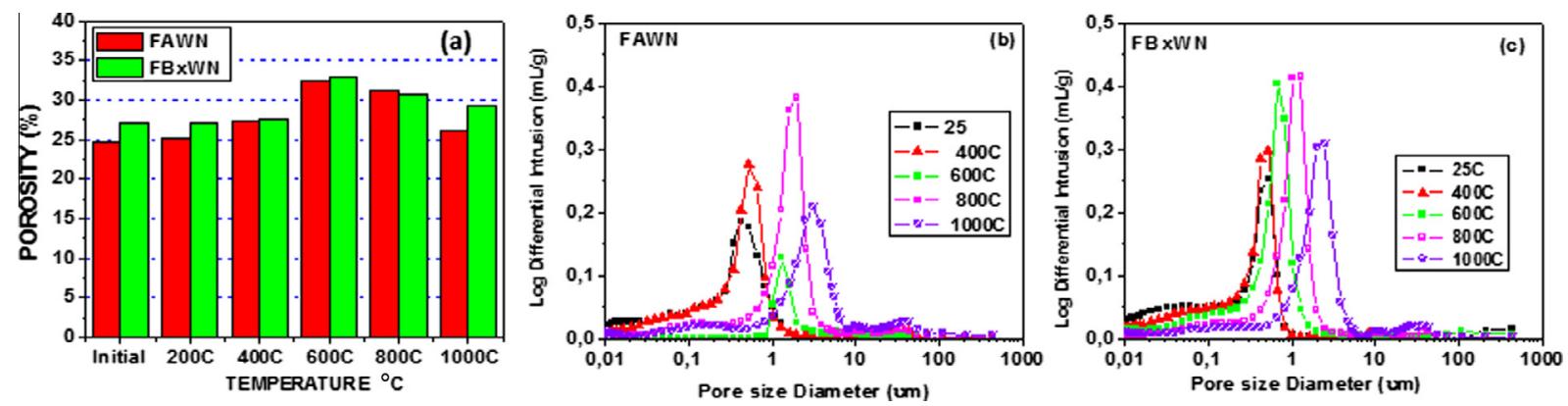

Fig. 12. (a) Variation in porosity and pore size distribution with temperature in alkaline cements: (b) FAWN and (c) FBxWN.

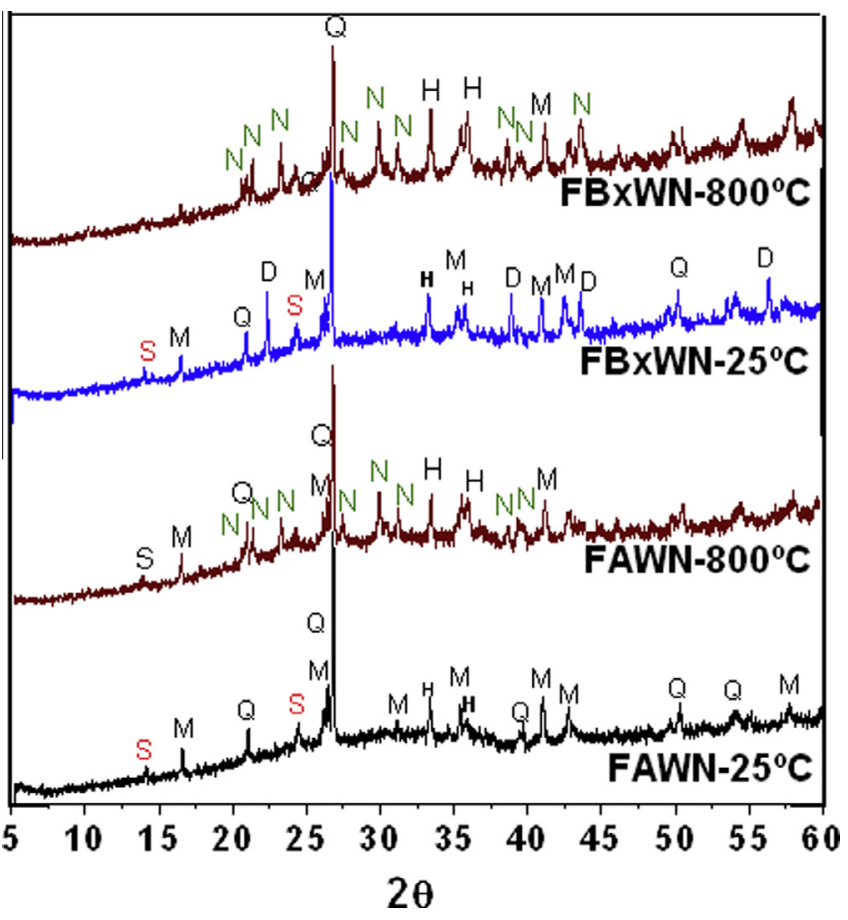

Fig. 13. XRD patterns for alkaline cements: (a) at ambient temperature; (b) after $1 \mathrm{~h}$ at $800^{\circ} \mathrm{C}$ followed by abrupt cooling to ambient temperature legend: $\mathrm{Q}=$ quartz (46-1045); $\mathrm{M}=$ mullite (01-0613); $\mathrm{H}=$ hæmatite (87-1165); $\mathrm{D}=$ diaspore (810465); $\mathrm{S}=$ sodalite (11-0401); $\mathrm{N}=$ nepheline (83-2372).

the trials conducted. The reasons for such behaviour are not fully clear. The two cements had the same initial and final phases with the exception of the diaspore present in bauxite, one of the constituents of FBxWN, which disappeared at $800{ }^{\circ} \mathrm{C}$. Their pre- and post-firing porosity and pore size distribution were also very similar (see Fig. 12). Another nearly matching feature was their alkali contents (activated with the same amount and type of alkaline solution, see Table 2), although certain variations were observed in their $\mathrm{SiO}_{2} / \mathrm{Al}_{2} \mathrm{O}_{3}$ ratios (1.86 and 1.41 for FAWN and $\mathrm{FBxWN}$, respectively) due to the higher proportion of $\mathrm{Al}_{2} \mathrm{O}_{3}$ in bauxite-containing FBxWN.

Nonetheless, prior studies showed that bauxite per se does not react during alkali activation and that in blends with fly ash the initial mechanical strength values decline with rising proportions of bauxite [40]. In those studies bauxite contents of 10 to $15 \%$ were seen to induce slight rises in alkali-activated fly ash cement strength, however, such as observed in FBxWN with respect to FAWN. In FBxWN, bauxite acted essentially as a matrix-strengthening filler, which would partly explain the material's slightly higher compressive and bending strength. Inasmuch as bauxite is used in heat-resistant materials [29,41], a certain percentage was included in one of the cements studied here. As noted, its presence did slightly improve alkaline cement performance at high temperatures.

\section{Conclusions}

The present findings revealed that the behaviour at high temperatures of cements based on the alkaline activation of aluminosilicates (high-silica, high-aluminium, low-calcium materials) is clearly distinct from the behaviour observed in Portland cement. While the latter exhibits a drastic decline in bending and compressive strength with rising temperature due to brittle failure, alkaline cements retain and even improve their compressive strength up to temperatures of around $600{ }^{\circ} \mathrm{C}$.

The most prominent findings of this study are as follows.

- In the $25-600{ }^{\circ} \mathrm{C}$ temperature range, irrespective of the type of trial (in vivo or post-firing), bending and compressive strength, fracture toughness and modulus of elasticity maintaining or increasing with temperature in alkaline cements. Brittle failure is observed in all cases.

- The pseudo-plastic strain taking place in alkaline cements during in vivo trials at temperatures of over $600{ }^{\circ} \mathrm{C}$ prompts a decline in mechanical strength, although the material does not necessarily fail.

- The formation of a pseudo-viscous phase at around $600{ }^{\circ} \mathrm{C}$ may largely explain why some of the cracks in the material are partially or wholly filled, rendering crack spread and propagation more complex. The result is macroscopic deformation that may sound a warning of possible structural collapse before the fact.

- An original and unprecedented procedure is introduced for determining plane strain fracture toughness $\left(K_{\mathrm{IC}}\right)$ at different temperatures in prismatic $(5 \times 4 \times 30 \mathrm{~mm})$ specimens paste with a $1-\mathrm{mm}$ indentation for OPC (reference) and two alkaline cements (FAWN and FBxWN)

- The two alkaline cements tested, FAWN and FBxWN, show similar mechanical strength in both the in vivo and post-firing trials. The slightly higher heat-resistant values recorded for FBxWN may be associated with the presence of (15\%) bauxite in its composition.

\section{Acknowledgements}

This study was funded by the Spanish Ministry of the Economy and Competitive Affairs under research projects MAT2012-38541-C02-02 and BIA2013-43293-R.

This work has been also financial supported by Comunidad de Madrid (MULTIMAT-CHALLENGE, Ref: S2013/MIT-2862). 


\section{References}

Taylor HFW. Cement chemistry. 2nd ed. Thomas Telford; 1997. 134.

Lea's, chemistry of cement and concrete. 4th ed. London: Arnold; 1998.

Neville AM. Properties of concrete. Essex: Logman; 1995.

Krivenco P, Alkaline cements and concretes, Proceedings First Int. Conf. Alkaline Cements and Concretes, 1994; vol. 1, SRIBM, Kiev, Ukraine, 11-129.

Palomo A, Grutzeck MW, Blanco MT. Alkali-activated fly ashes. A cement for the future. Cem Concr Res 1999;29:1323-9.

Duxson P, Fernández-Jiménez A, Provis JL, Lukey GC, Palomo A, van Deventer JSJ. Geopolymer technology: the current state of the art. J Mater Sci 2007;42:2917-33.

Shi C, Krivenko PV, Roy D. Alkali-activated cements and concretes. Taylor \& Francis; 2006.

Provis J, van Deventer JSJ. Geopolymers, structure, processing, properties and industrial applications. In: Provis J, van Deventer JSJ, editors. Woodhead Publishing Limited; 2009. ISBN 978-1-84569-449-4.

Provis J, van Deventer JSJ. Alkali activated materials. State of the art report. RILEM TC 224-AAM, Springer; 2014. ISBN 978-94-007-7671-5. DOI: http:// dx.doi.org/10.1007/978-94-007-7672-2.

Fernández-Jiménez A, Palomo A. Composition and microstructure of alkali activated fly ash mortars. Effect of the activator. Cem Concr Res 2005;35: 1984-92.

Garcia-Lodeiro I, Palomo A, Fernández-Jiménez A, Macphee DE. Compatibility studies between $\mathrm{N}-\mathrm{A}-\mathrm{S}-\mathrm{H}$ and $\mathrm{C}-\mathrm{A}-\mathrm{S}-\mathrm{H}$ gels. Study in the ternary diagram $\mathrm{Na}_{2} \mathrm{O}-\mathrm{CaO}-\mathrm{Al}_{2} \mathrm{O}_{3}-\mathrm{SiO}_{2}-\mathrm{H}_{2} \mathrm{O}$. Cem Concr Res 2011;41:923-31.

Kovalchuk G, Fernández-Jiménez A, Palomo A. Alkali activated fly ashes. Effect of thermal curing conditions on mechanical and microstructural development - Part II. Fuel 2007;86:315-22.

Criado M, Fernández-Jiménez A, Palomo A. Alkali activation of fly ash. Part 3: effect of curing conditions on reaction and its graphical description. Fuel 2010;89:3185-92.

Fernández-Jiménez A, Palomo A, López-Hombrados C. Some engineering properties of alkali activated fly ash concrete. ACI Mater J 2006;103(2): 106-12.

Fernández-Jiménez A, García-Lodeiro I, Palomo A. Durability of alkali-activated fly ash cementitious materials. J Mater Sci 2007;42:3055-65.

García-Lodeiro I, Palomo A, Fernández-Jiménez A. Alkali-aggregate reaction in activated fly ash Systems. Cem Concr Res 2007;37(2):175-83.

Allahverdi A, Skvara F. Nitric acid attack on hardened paste of geopolymeric cements. Ceram-Silik 2001;45(4):143-9.

Allahverdi A, Skvara F. Sulfuric acid attack on hardened paste of geopolymer cements. Part 1. Mechanisms of corrosion at relatively high concentrations. Ceram-Silik 2005;49:225.

Barbosa VFF, Mackenzie KJD. Thermal behaviour of inorganic geopolymers and composites derived from sodium polysialate. Mater Res Bull 2003;38:319-31.

Bakharev T. Thermal behaviour of geopolymers prepared using class F fly as and elevated temperature curing. Cem Concr Res 2006:36:1134-47.

Krivenko PV, Kovalchuk GY. Directed synthesis of alkaline aluminosilicate minerals in a geocement matrix. J Mater Sci 2007;42:2944-52.

Fernández-Jiménez A, Palomo A, Pastor JY, Martín A. New cementitious materials based on alkali activated fly ash: performance at high temperature. J Am Ceram Soc 2008;91(80):3308-14.
Fernández-Jiménez A, Pastor JY, Martín A, Palomo A. High-temperature resistance in alkali-activated cement. J Am Ceram Soc 2010;93(10). 3417 3417.

Davidovits J. Geopolymer, chemistry and applications. Saint-Quentin, France: Institut geopolimere; 2008.

Kong DLY, Sanjayan JG, Sagoe-Crentsil K. Comparative performance of geopolymers made with metakaolin and fly ash after exposure to elevated temperatures. Cem Concr Res 2007;37(12):1583-9.

Provis JL, Yong CZ, Duxson P, van Deventer JSJ. Correlating mechanical and thermal properties of sodium silicate-fly ash geopolymers. Colloids Surf A Physicochem Eng Aspects 2009;336:57-63.

Temuujin J, Rickard W, van Riessen A. Characterization of various fly ashes for preparation of geopolymers with advanced applications. Adv Powder Technol 2013;24(2):495-8.

Kong DLY, Sanjayan JG. Damage behaviour of geopolymer composites exposed to elevated temperatures. Cem Concr Compos 2008;30:986-91.

Ye J, Zhang W, Shi D. Effect of elevated temperature on the properties of geopolymer synthesized from calcined ore-dressing tailing of bauxite and ground-granulated blast furnace slag. Constr Build Mater 2014;69:41-8.

Ruiz-Santaquiteria C, Skibsted J, Fernández-Jiménez A, Palomo A. Alkaline solution/binder ratio as a determining factor in the alkaline activation of aluminosilicates. Cem Concr Res 2012;42:1242-51.

Ruiz-Santaquiteria C, Fernández-Jiménez A, Skibsted J, Palomo A. Clay reactivity: production of alkali activated cements. Appl Clay Sci 2013;73:11-6. Thimoshenko SP. Strength of materials. 3rd ed. Princeton, New Jersey: D. Van Nostrand Company Inc.; 1956. part II, p. 169.

Guinea GV, Pastor JY, Planas J, Elices M. Stress intensity factor, compliance and CMOD for general three-point-bend beam. Int J Fract 1998;89:103-16.

Vázquez-Acosta F, Torres-Martínez L, López-González W, Ibarra-Rodríguez J. Influence of iron content on the color of the $\mathrm{C}_{3} \mathrm{~A}-\mathrm{Fe}_{2} \mathrm{O}_{3}$ system synthesized under different conditions of temperature, atmosphere and cooling. Ceram Int 2012;38(4):3261-72.

Sukontasukkul P, Pomchiengpin W, Songpiriyakij S. Post-crack (or post-peak) flexural response and toughness of fiber reinforced concrete after exposure to high temperature. Constr Build Mater 2010;24:1967-74.

Elices M, Planas J. Fracture mechanics parameters of concrete: an overview. Adv Cem Based Mater 1996;4(3-4):116-27.

Sarker Prabir K, Haque R, Ramgolam VK. Fracture behaviour of heat cured fly ash based geopolymer concrete. Mater Design 2013;44:580-6.

Djaknoun S, Ouedraogo E, Ahned Benyahia A. Characterisation of behaviour of high performance mortar subjected to high temperature. Constr Build Mater 2012;28:176-86.

Zhang HY, Kodur V, Qi SWL, Cao L, Wu B. Development of metakaolin-fly ash based geopolymers for fire resistance applications. Constr Build Mater 2014;55:38-45.

Ruiz-Santaquiteria C. Materias primas alternativas para el desarrollo de nuevos cementos: activación alcalina de vidrio silicoaluminosos [Ph.D. thesis]. Spain: Universidad Autónoma de Madrid; 2013.

Ouedraogo E, Roosefid M, Prompt N, Deteuf C. Refractory concretes uniaxial compression behaviour under high temperature testing conditions. J Eur Ceram Soc 2011;31:2763-74. 